\title{
Effect of Age of Seedling and Number of Seedlings per Hill on Growth and Yield of Low land Rice Cultivation in Asia - A Review
}

\author{
G. N. Gurjar ${ }^{1}$, Sanjay Swami ${ }^{1}$ and N. K. Meena ${ }^{2}$ \\ ${ }^{1}$ School of Natural Resource Management, Central Agricultural University, \\ CPGS, Umiam, Meghalaya-793103, India \\ ${ }^{2}$ School of Social Sciences, CPGS CAU, Umiam, Meghalaya, India \\ *Corresponding author
}

\begin{tabular}{|l|}
\hline Ke y w o r d s \\
Age, Seedling, \\
$\begin{array}{l}\text { Non-monetary } \\
\text { input, Eco-friendly, } \\
\text { Cost effective }\end{array}$ \\
\hline Article Info \\
\hline $\begin{array}{l}\text { Accepted: } \\
\text { 28 April } 2018 \\
\text { Available Online: } \\
\text { 10 June } 2018\end{array}$ \\
\hline
\end{tabular}

\section{Introduction}

Rice is the staple food crop of India providing major source of the food energy for more than half of the world population. It is grown in $155 \mathrm{M}$ ha area at global levels and around 45 $\mathrm{M}$ ha area in India. India occupies first place in area of rice in the world and second position in production. Rice is grown in most of the states across the country under different agro techniques. Rice play a major role in Indian agriculture. It provides $43 \%$ of total
Among the various agro-techniques uprooting aged seedlings and ideal number of seedling/hill are the two supreme important agronomic practices for attainment the higher grain yield of rice, under both sufficient and limited resource conditions. Number of seedling per hill theatres a most important role in relative to maximise grain yield of rice and also for communal rice varieties. If fewer number of seedlings per hill is used, the probable yield cannot be realize, If extra seedlings is used it might not be cost effective. It becomes imperative therefore to find out the optimum number of seedlings required per hill for producing high number of panicles, number of effective tillers per hill at harvest, number of filled grains per panicle, optimum size and shape of grains and ultimately higher yield of high quality and quantity both. The suitable time of nursery preparation and transplanting of seedlings at early stage is most important to get good results from the crop and also the optimum number of seedlings according to status of soil and management practices is one of the non-monetary inputs for farmers especially in resource limited conditions. Such techniques of crop production not only adopted in developing countries but also in developed countries because it has been reported from across the globe about how much such techniques are important to increase agricultural production along with cost effective, environment friendly and conserve natural resource too. calories requirement for more than $70 \%$ of population living in hilly and plain regions of the country Anonymous (2006). In India, rice is grown under various climatic condition and different techniques of crop production in hilly area of north east India to plain area of Punjab, Haryana, Rajasthan, Uttar Pradesh etc.

The saying "Rice is life" is the most adoptable for country like India as rice crop has been playing a vital part to our national 
food security. Rice productivity and production will be needed to increase accordingly increasing food demand and population. The introduction and cultivation of fertilizer responsive and dwarf varieties cause the increased food grain production in past $70^{\text {th }}$ century known as 'Green Revolution'. But now a days those techniques are no longer suitable to increase in potential yield and productivity in both area and time dimension under changing climate scenario and their yield is at plateau. So, we need another techniques of crop production those are environmentally sound, cost effective and requires low inputs such as number of seedlings per hill and age of transplanting seedlings. Because such techniques are cost effective i.e. farmers can easily adopt without changing in input requirement. What we have to do is to change in transplanting time and number of transplanted seedlings without interfering in other management and cultural practices. This techniques is most famous because if we suggest farmers to use hygienic techniques some of them may be but not all because of limited resources and credit problems as well as other factors like climate, topography and input use supply and plant management factors.

\section{Effect of age of seedling on the growth and yield of rice}

\section{Effect of age of seedling}

Rajendran and Ganesa (2014) found that the effect of age of seedlings at transplanting is considered for influencing grain yield in water scarce rice production system, primarily by laying the foundation for determining the number of panicle at harvest. Seedling age at transplanting is an important factor for uniform stand of rice and its growth and yield. Further Naidu et al., (2013) reported that in combination of four different ages of seedlings (8, 12, 16 and 20 days old) and four planting pattern $(20 \times 20 \mathrm{~cm}, 25 \times 25 \mathrm{~cm}, 30 \times 30$ $\mathrm{cm}$ and $35 \times 35 \mathrm{~cm}$ ) on rice. Transplanting of 12 days old seedling resulted in highest plant height, grain yield, grain protein and NPK uptake. Ali et al., (2013) further observed the effect of seedlings age on tillering behaviour, growth dynamics, yield and yield contributing characters of BRRI dhan 28 and found that 15 days old seedlings provided greater ability to tiller production, dry matter accumulation and more leaf area, more effective tiller/hill, filled grains/panicle, 1000 grain weight and finally grain yield and observed that 30 day old seedlings when transplanted at a spacing of 20 $\mathrm{cm} \times 15 \mathrm{~cm}$. from 7 August to 7 September gave more number of tiller/ $\mathrm{m} 2$, panicles/ $\mathrm{m} 2$ and grains / panicle which resulted in higher grain yield. Thus, fine rice basmati PNR and Basmati -D were most suitable to obtain higher grain yield when planted within 17-21 August (Mannan et al.,2009).(El-rewainy et $a l ., 2007)$ also observed that the transplanting of youngest seedling ( 25 days old) produced highest significant value of leaf area $\left(\mathrm{cm}^{2}\right)$ and total dry weight (g/ hill) as well as grain and most of its component of both cultivars (Sakha 101and sakha 102), while the 30 days old seedling gives the tallest plant. Further explained that planting of four weeks old seedlings recorded higher number of ripened grains than five and six week old seedlings during kharif season (Sahoo and Rout, 2004). Rajesh and Thanunathan (2003) observed that planting of 40 days old seedling with 2 seedlings/ hill at a spacing of $20 \times 15 \mathrm{~cm}$ was optimum in increasing the yield of Kambanchamba rice. The effect of seedling age and number of seedling/ hill on rice growth and yield. The results revealed that seedling of 25- to- 35 days old produced significantly higher number of tillers and productive tiller/hill, paddy and straw yields compared with 55-days old seedlings. In another experiment also the transplanting of 2 and 3 seedlings/hill of 35 days old gave more promising results (Ashraf et al., 1999) and 
Further reported that transplanting of 35-days old seedlings with 4-5 or 6-7 seedlings/hill of medium duration were gave significantly the highest grain yield than 25- or 45-day old seedlings (Channabasappa et al., (1997).

\section{Effect of number of seedling/hill on growth and yield of rice}

\section{Effect of number of seedlings on growth characters}

Chauhan (2005) reported that transplanting of 3 seedlings per hill recorded maximum plant height $(97.83 \mathrm{~cm})$ and dry matter accumulation per hill (19.08g) as compared to 1 and 2 seedlings per hill. Also found that plant height did not influenced significantly due to number of seedlings ( 1 and 2 seedlings per hill) in rice hybrid 'III you 98' under agro-ecological situations of China(Zhang et al.,2004).Pariyani and Naik (2004) reported from Jabalpur, planting of 1 or 2seedlings per hill did not showed significant difference on plant height with rice hybrids 'PA 6201' and 'PAC 801'.Nayak et al., (2003) laid down an experiment at Bhubaneshwar on hybrid rice 'PA 6201' and revealed that total tillers, effective tillers per hill, leaf area index and dry matter accumulation per clump were significantly more with planted 2 seedlings per hill than planted with 1 seedlings per hill. Plant height recorded significantly more with 1 seedling per hill than the 2 seedlings per hill. Dongarwar et al., (2002) studied the response of number of seedlings per hill on hybrid rice 'Sahyadri' and observe that transplanting of 1 seedling per hill was at par with transplanting of 2 seedlings per hill in respect of plant height and total tillers per $\mathrm{m}^{2}$. Verma et al., (2002) carried out an investigation at Raipur on hybrid rice 'PA 6201 ' and stated that crop planted with 3 seedlings per hill produced higher number of productive tillers than those planted with 1 or 2 seedlings per hill. Molla (2001) conducted a field experiment at West Bengal with rice hybrids 'PA 6201' and 'CNRH 3', revealed that 2 seedlings per hill produced significantly higher number of tillers per $\mathrm{m} 2$ as compared to 1 seedlings per hill. Shrirame et al., (2000) found that 2 seedlings per hill gave significantly higher number of tillers per hill than 1 and 3 seedlings per hill. Plant height and leaf area index were not affected significantly by number of seedlings per hill. Channabasappa et al., (1998) reported from Karnataka that plant height was not affected significantly due to varying number of seedlings per hill but the tallest plants were recorded with 4-5 seedlings per hill as compared to 2-3 and 6-7 seedlings per hill. Srivatav and Tripathi (1998) a field experiment was conducted at Raipur with rice hybrid 'PA 6201' and cv. 'R 320-300' and revealed that crop transplanted with 2 seedlings per hill recorded significantly more effective tillers per m2 (316) as compared to transplanted with 1 (308) and 3 seedlings per hill (309).

Banik et al., (1997) reported that among the different number of seedlings per hill, 4 seedlings per hill recorded maximum plant height, dry matter production and number of tillers per hill and leaf area index than 2, 6 and 8 seedlings per hill. Srinivasulu (1997) conducted a field experiment with two hybrids 'APHR 1' and 'APHR 2' and one cv. 'Chaitanya' at Bapatla and concluded that the crop transplanted with 2 seedlings per hill produced significantly higher productive tillers per $m 2$ (292) than the crop transplanted with 1 seedling per hill. Gupta (1996) found that transplanting of 1 seedling per hill significantly increased plant height, than the higher number of seedlings per hill. Cai et al., (1991) found that the tiller number also increased with increased in seedlings number from 1 to 3 per hill. Shah et al., (1991) from a field experiment with cv ' $\mathrm{K}$ 39' using 3, 4, 5 and 6 seedlings per hill found that plant 
height increased with decreased seedlings per hill, on the other hand they were also found that tiller number increased with increased number of seedlings per hill from 3 to 6 .

Zhang and Hung (1990) reported from China, that there was significant increase in the plant height due to increase in number of seedlings from 1 to 5 per hill. 5 seedlings per hill recorded significantly more plant height $(84.4$ $\mathrm{cm})$ than the 1 seedling per hill $(79.0 \mathrm{~cm}), 2$ seedlings per hill $(82.2 \mathrm{~cm}), 3$ seedlings per hill $(81.8 \mathrm{~cm})$ and 4 seedlings $(80.4 \mathrm{~cm})$ per hill. Budhar et al., (1989) observed that there was no significant difference in plant height with 2 or 4 seedlings per hill. Das et al., (1988) observed that increasing the number of seedlings per hill increased growth characters like plant height, dry matter production per hill, leaf area index and functional leaves per hill with 5 seedlings per hill and also Siddhu et al., (1988) found that rice crop transplanted with 2 seedlings per hill produced higher number of tillers per hill, number of leaves per hill and dry matter production per $\mathrm{m} 2$ as compared to 1 seedling per hill. Shah et al., (1987) number of seedlings per hill markedly influenced the plant height of rice cv. 'K 39'. 3 seedlings per hill recorded more height $(95.6 \mathrm{~cm})$ than 6 seedlings per hill $(92.6 \mathrm{~cm})$. Baird et al., (1985) also reported that tillers density increased significantly with increasing seedling rate and established plant stand throughout the growing season. Reddy and Mitra (1984) observed that tiller number per $\mathrm{m} 2$ decreased with more than 2 seedlings per hill when planted.

\section{Effect of number of seedlings per hill on yield and yield contributing characters}

Thawait et al., (2014) observed that transplanting of 2-3 seedling/hill in the spacing of $25 \mathrm{~cm} \quad x \quad 25 \mathrm{~cm}$ recorded significantly highest plant height (129.64), number of tillers (15.70 tillers/hill), dry matter accumulation (102.65 g/hill) and yield attributing characters along with highest grain yield $(38.20 \mathrm{q} / \mathrm{ha})$ and straw yield (77.91q/ha). Further Ehsanullah et al., (2012) observed the effect of seedlings density per hill have a strong influence on rice growth and grain yield due to competitive effects both on the vegetative and reproductive development. Panicle length, number of branches per panicle and kernels per panicle remained unaffected at varying levels of rice seedlings per hill. 2, 3 and 4 seedlings/hill resulted in maximum rice kernel yield and harvest index due to enhanced number of panicle bearing tillers and 1000- kernel weight. Ahmad and Hasanuzzaman (2012) observed that the highest grain yield (497 $\mathrm{g} / \mathrm{m} 2$ ) were observed in the treatment having combination of two seedling/hill. Roshan et al., (2011) observed that the highest grain yield (4073.38 kg/ ha) was obtained from plant spacing $15 \times 15 \mathrm{~cm}$ and number of 5 seedling/ hill as compare to the other plant spacing like $20 \times 20 \mathrm{~cm}, 25 \times 25 \mathrm{~cm}$ and 1, 3, 7 number of seedling / hill.

Naser et al., (2011) conducted experiments with three plant spacing $(15 \mathrm{x} 15 \mathrm{~cm}$ : $20 \mathrm{x}$ 20cm: $25 \times 25 \mathrm{~cm})$ and four different seedlings/hill (1 seedling/hill: 3 seedlings/hill: 5 seedlings/hill: 7 seedlings/hill) during 2008 in Iran. The result revealed that higher grain yield with $3921.67 \mathrm{~kg} / \mathrm{ha}$ was obtained from transplanting of 5 seedlings/hill. Hasanuzzman et al., (2009) the results revealed that both the plant spacing and no. of seedlings/hill showed a significant effect on the tillering and dry matter yield of transplanted rice. At all the growth stages wider row spacing $(25 \mathrm{~cm} \times 20 \mathrm{~cm})$ and higher number of seedlings/ hill (3 and 4) showed maximum tillering. Islam et al., (2008) observed the effect of nitrogen $(\mathrm{N})$ and number of seedlings/hill on the yield and yield component of transplanted aman rice cv. BRRI dhan 33. Transplanting of three 
seedlings/hill was the best in respect of plant height, tiller/ hill, effective tillers/ hill, grains/ panicle and grain yield (4.07 t/ha). Safdar et al., (2008) observed that maximum plant height $(172.1 \mathrm{~cm})$, grains/ panicle $(119.3)$, 1000 grain weight (21.58) and paddy yield $(3.95 \mathrm{t} / \mathrm{ha})$ were highest in 16thJuly transplanting date. Chauhan (2005) a field investigation carried out at C.S.A.U.A\&T., Kanpur and found that crop planted with 3 seedlings per hill produced higher panicle length $(23.02 \mathrm{~cm})$, number rachilae per panicles (10.36), weight per panicle $(2.76 \mathrm{~g})$ number of grains per panicle (108.74) and grain yield (45.65 q/ha) than that planted with 1 and 2 seedlings per hill.

Pariyani and Naik (2004) a field trial conducted at Jabalpur on rice hybrids 'PA 6201', 'PHB 71' and 'PAC 801' and reported that planting of 1 or 2 seedlings per hill did not showed significant variations in yield attributes and yield. However, 'PHB 71' gave 20.6 and 10.3 per cent higher grain yield over 'PA 6201' and 'PAC 801', respectively. Zhang et al., (2004) worked on hybrid rice 'III You 98' at China and found that crop planted with 2 seedlings per hill recorded significantly higher grain yield over the 1 seedling per hill, but differences in panicle length and 1000-grain weight were nonsignificant. They were also reported that crop transplanted of plant density 281300 hills per hectare with 2 seedlings per hill or plant density 365800 hills per hectare with 1 seedling per hill for obtaining yield more than 10.0 tonnes per hectare and further Nayak et al., (2003) carried out a field investigation at Bubaneshwar during Kharif 1999 and 2000 on hybrid rice 'PA 6201' and revealed that grain and straw yield were significantly more under 2 seedlings per hill than planting of 1 seedling per hill. The increase in grain yield was 6.7 and 9.7 per cent and in straw yield was 6.0 and 9.5 per cent during the 1999 and 2000, respectively. However, fertile spikelets per ear and 1000-grain weight did not showed significant difference due to number of seedlings per hill during both the year. Rao and Moorthy (2003) reported from Cuttack (Orissa) that planting of 1 seedling per hill was good as compared to 2 seedlings per hill in term of grain yield indicating the scope to reduce the seed rate.

Dongarwar et al., (2002) carried out a field investigation at Agricultural Research Station, Bhandara on rice hybrid 'Sahyadrii' and noticed that length of panicle, 1000-grain weight, grain and straw yield did not significantly differ due to transplanting of 1 or 2 seedlings per hill. However, 1 seedling per hill recorded numerically higher length of panicle $(33.0 \mathrm{~cm})$, grain $31.32(\mathrm{q} / \mathrm{ha})$ and straw yield $(47.40 \mathrm{~g} / \mathrm{ha})$ than the 2 seedlings per hill. Obulamma and Reddeppa (2002) a field trial was conducted on rice hybris 'DRRH 1' and 'APHR 2' at southern agro climatic zone of Andhra Pradesh and revealed that crop planted with 1 seedling per hill recorded significantly higher grain yield than planted with 2 and 3 seedlings per hill. Verma et al., (2002). the results of field experiment conducted at Raipur on rice hybrid 'PA 6201' at Raipur during Kharif 1999 indicated that crop planted with 3 seedlings per hill produced higher grain yield and harvest index than those planted with 1 and 2 seedlings per hill. Molla (2001) conducted an experiment at West Bengal and observed that 2 seedlings per hill produced significantly more higher number of panicles per $\mathrm{m} 2$ and grain yield as compared to 1 seedling per hill with rice hybrids 'PA 6201', 'CNRH 3' and high yielding variety 'IET 4786'. Shrirame et al., (2000) reported that 2 seedlings per hill gave significantly higher grain and straw yield than 1 and 3 seedlings per hill. However, 1 seedling per hill gave significantly higher harvest index than that with 2 and 3 seedlings per hill. Jati (1999) reported that number of seedlings per hill had no significant effect on 
panicle length and harvest index in rice hybrids 'PA 6201' and 'NPH 4507'. However, 1 seedling per hill recorded numerically higher length of panicle (32.2 $\mathrm{cm})$ and harvest index (44.2. \%) than 2 seedlings per hill.

Rao et al., (1999) worked at Bangalore and found that seedling densities (1 or 2 seedlings per hill) had no effect on grain yield in hybrid rice. Rajarathinam and Balasubramaniyan (1999) worked on hybrid rice 'CORH 2' at Madurai, Tamil Nadu and found that 1 or 2 seedlings per hill did not effect grain yield significantly. Srinivasulu (1999b) worked at Baptla, Andhra Pradesh and concluded that significantly higher grain yield $(6.11 \mathrm{t} / \mathrm{ha})$ with 2 seedlings per hill than 1 seedling per hill in rice hybrids 'APHR 1' 'APHR 2' and local check 'Chaitanya'. Reddy and Mitra (1984) found that yield of rice was decreased when transplanted more than 2 seedlings per hill. Channabasappa et al., (1998) studied the response of late transplanted rice to number of seedlings at Karnataka and concluded that under late planting condition rice yield increased with increase in number of seedlings per hill. Rice transplanted with 4-5 or 6-7 seedling per hill produced higher grain yield than transplanted with 2-3 seedlings per hill further increase in number of seedlings beyond 4-5 had no significant effect on grain yield.

Prasad et al., (1998) carried out field investigation at New Delhi with rice cv. 'Pusa 834' and 'Pusa HR3' and noticed that crop planted with 3 seedlings per hill produced higher grain yield (5.6 t/ha) as compared to planted with 2 seedlings per hill (3.5 t/ha).Srivastav and Tripathi (1998) studied the response of rice hybrid 'PA 6201' and cv. 'R 320-300' to number of seedlings at Raipur during Kharif 1995. They were reported that crop transplanted with 2 seedlings per hill gave significantly higher grain yield (6.57 t/ha) as compare to crop transplanted with 1 (6.24 t/ha) and 3 seedlings per hill (6.28 t/ha). Banik et al., (1997) reported that rice transplanted with 4 seedlings per hill produced grain yield of 42.16 quintal per hectare, which was $3.23,4.49$ and 19.91 per cent more than the grain yield obtained with 2, 6 and 8 seedlings per hill, respectively. CRRI (1997) the field trials was conducted during Kharif 1997 with two rice hybrids at 10 locations and revealed that 2 seedlings per hill recorded significantly higher grain yield than 1 seedling per hill at all locations (DRR, 1997). Experiment conducted at CRRI, Cuttack with hybrid rice 'VRH 2' revealed that there was no significant difference in grain yield due to transplanting of 1 to 3 seedlings per hill. Srinivash (1997) reported that 2 seedlings per hill recorded significantly higher grain yield than the 1 seedling per hill with hybrid rice. Srinivasulu (1997) recorded equal number of filled grains per panicle (116) in hybrids 'APHR 1', 'APHR 2' and cv. 'Chaitanya, raised with 1 and 2 seedlings per hill but 1 seedling per hill resulted in numerically higher test weight (21.39 g) than 2 seedlings per hill. Gupta (1996) reported that rice crop planted with 4 seedlings per hill recorded significantly higher length of panicle, grains per panicle and 1000-grain weight over the 2 and 6 seedlings per hill, the 4 seedlings per hill also recorded significantly higher grain yield ( $36.25 \mathrm{~g} / \mathrm{ha})$ over the 2 and 6 seedlings per hill, 4 seedlings per hill led to 14.4 and 23.5 per cent higher grain yield than the 2 and 6 seedlings per hill, respectively. Bali et al., (1995) worked at Jammu \& Kashmir and found that number of grains per panicle, 1000-grain weight and straw yield were significantly higher with 3 seedlings per hill. However, grain yield did not significantly influenced due to 3 and 6 seedlings per hill but found an increase of 17.1 and 13.4 per cent over the 9 seedlings per hill, respectively. Yield differences were not significant (DRR, 1996). Chaudhury 
(1991), recorded significantly higher panicle length $(28.98 \mathrm{~cm})$ and number of fertile grains (90.77) with planting of 2 seedlings per hill as compared to planting of 4 and 6 seedlings per hill in cv. 'Rambha'. Shah et al., (1991) studied the effect of number of seedlings (3, 4,5 and 6 seedlings per hill) on rice cv. ' $\mathrm{K}$ 39 ' and revealed that 1000-grain weight and number of panicle per plant were highest with 3 seedlings per hill whereas grain yield was highest with transplanted 5 seedlings per hill. Zhang and Hung (1990) reported from China, that there was significant decrease in number of panicles per plant, length of panicle, fertile spikelets per panicle and 1000-grain weight due to increase in number of seedlings per hill from 2 to 5.Chandrakar and Chandravanshi (1988) transplanted 2 or 4 seedlings per hill gave higher yield of grain. Sawa et al., (1988) noticed that rice transplanted with 2 seedlings per hill produced maximum grain yield than transplanted with 1 seedlings per hill. Sidhhu et al., (1988) conducted a field experiment at P.A.U., Ludhiana and found that rice transplanted with 2 seedlings per hill produced maximum grain yield (10.6 t/ha) than the 1 seedlings per hill. Pandey et al., (1987) reported that rice transplanted with 1 , 2, 3 and 4 seedlings per hill gave grain yield of 3.78, 5.09, 5.00 and 4.94 tonnes per hectare, respectively. Raghuvansi et al., (1986) reported that there was no significant differences in yield with transplanted 3 or 5 seedlings per hill.

From the results of various experiments on effect of age of seedling and number of seedlings per hill on growth and yield of rice has been shown that transplanting of 15 days old seedling and 2 seedlings per hill had significant impact on the grain yield with higher monetary return compared to others. This treatment not only gave higher grain yield but also had higher by net return and cost: benefit ratio. Because the younger seedlings have the capacity to early establishment and start growing at a faster rate due to higher root development leads to more nutrient uptake and weeds suppression ability in comparison to aged seedlings.

\section{Acknowledgement}

We are thankful to Dr. Sanjay Swami for helping and guiding during paper writing and also to School of Natural Resource Management, Central Agricultural University, CPGS, Umiam, Meghalaya,

\section{References}

Ahmad, S. and Hasanuzzaman, M. (2012). Integrated effect of plant density, $\mathrm{N}$ rates and irrigation regimes on the biomass production content, PAR use efficiencies and water productivity of rice under irrigated semi-arid environment.Not. Bot. Horti. Agrobio., 40(1): 201-211.

Ali, M.S., Hasan, M.A., Sikder, S., Islam, M.R. and Hafiz, M.H.R. (2013). Effect of seedling age and water management on the performance of boro rice (Oryza sativa L.) variety BRRI Dhan 28.The Agriculturists, 11(2): 28-37.

Anonymous (2006). Tamil Nadu Statistics at a glance - 2005, Government of Tamil Nadu. In: http://www.tn.gov.in/misc/tnatglance.ht $\mathrm{m}$.

Ashraf, M., Khalid, A. and Ali, K. (1999). Effect of seedling age and density on growth and yield of rice under saline soil. Pak. J. Bio. Sci., 2(3): 860-862.

Baird, C., Miller, J., Hill, E. and Stacy, R.R. (1985). Plant population effect on growth and yield of water seeded rice. Agron. J., 83: 291-297.

Bali, A.S., Singh, K.N., Bali, A.S., Ganai, B.A. and Hasan, B. (1995). Effect of transplanting dates, number and age of 
seedling on rice. Indian J. Agron., 40(3): 504-507.

Banik, P., Sarkar, B., Samal, T., Ghosal, P.K. and Bagohi, D.K. (1997). Effect of different number and age of seedlings on rice. Indian J. Agron., 42(2): 265270.

Budhar, M.N., Palaniappan, S.P. and Rangaswamy, A. (1989). Effect of plant population on productivity of early duration rice 'CR 666-18'. Oryza, 26(3): 310.

Cai, Y.Z., Cheng, G.F., Wu, H.M. and Xue, Y.S. (1991). Investigation of target for yield components and the establishment of relative population for the high yielding Japonica rice hybrid ' $\mathrm{Han}$ You 102'. Acta Agric. Shanghai, 7(3): 41-45.

Chandrakar, B.L. and Chandrawansi, B.R. (1988). Effect of age and number of seedlings, spacing and fertilizer on tall Indica rice. Indian J. Agron., 32(2): 131-134.

Channabasappa, K.S., Reddy, B.G.M., Patil, S.G. and Kumar, M.D. (1998). Response of late transplanted rice to age, number of seedlings and fertilizer levels. Indian J. Agron., 43(4): 636-638.

Channabasppa, K.S., Reddy, B.G.M., Dines, K.M. (1997). Response of rice (Oryza sativa L.) genotypes to age and number of seedlings under late planted conditions. Karnataka J. Agric. Sci., 10(4):1184-1185.

Chaudhury, T.C. (1991). Effect of spacing and number of seedlings per hill on transplanted rice. Oryza, 28(1): 65-66.

Chauhan, S.S. (2005). Studies on the effect of number of seedlings per hill and varying zinc sulphate doses on paddy varieties under delayed planting condition.Ph.D. Thesis, C.S.A.U.A. \& T., Kanpur (Unpublished).

CRRI, (1997). Effect of method of planting, spacing and seedling densities on the performance of hybrid rice. Annual
Report 1997-98. Central Rice Research Institute, Cuttack., pp. 83-84.

Das, K., Biswal, D. and Pradhan, T. (1988). Effect of plant density and age of seedling on the growth and yield of rice. Oryza, 25(2): 191-194.

Dongarwar, U.R., Patankar, M.N. and Pawar, W.S. (2002). Response of hybrid rice to spacing and number of seedlings per hill and their effects on growth and yield. $J$. Soils Crops, 12(2): 248-249.

Ehsanullah, Khawar J., Ghulam, A., Mubshar, H. and Muhammad, R. (2012). Effect of nitrogen fertilization and seedling density on fine rice yield in Faisalabad, Pakistan. Soil Environ., 31(2): 152-156.

El-rewainy, I.M., Hamoud, S.A., Metwaly, T.F. and Sedeek, S.E. (2007). Response of two rice cultivars to different seedling ages and nitrogen levels. African Crop Sci. Confe. Proc., Vol. 8.pp:1937-1941.

Gupta, S.K. (1996). Effect of date of planting, number of seedlings and nitrogen on yield of rice. Indian J. Agron., 41(4): 581-583.

Hasanuzzman, M., Nahar, K., Roy, T.C., Rahman, M.L., Hossain, M.Z. and Ahmed, J.U. (2009). Tiller dynamics and dry matter production of transplanted rice as affected by plant spacing and number of seedlings per hill. Acad. J. Plant Sci., 2(3):162-168.

Islam, M.S., Hossain, M.A., Chowdhury, M.A.H. and Hannan, M.A. (2008). Effect of nitrogen and transplanting date on yield and yield components of aromatic rice. J. Bangladesh Agric. Univ., 6(2):291-296.

Jati, S. (1999). Cultural studies on hybrid rice M.Sc. (Ag.) Thesis, Orissa University of Agriculture and Technology, Bhubaneswar (Unpublished)

Mannan, M.A., Bhuiya, M.S.U., Hossain, S.M.A. and Akhand, M.I.M. (2009). Study on phenology and yielding ability 
of basmati fine rice genotypes as influenced by planting date in aman season. Bangladesh J. Agric. Res., 34(3):373-384.

Molla, M.A.H. (2001). Influence of seedling age and number of seedlings on yield attributes and yield of hybrid rice in the wet season. IRRN., 26(2): 73-74.

Naidu, G.j., Rao, K.T., Rao, A.U. and Reddy, D.S. (2013). Age of seedling and planting pattern on grain yield, protein content, NPK uptake and postharvest nutrient status of rice under SRI. $J$. Acade. Indust. Res., Vol 2:334-337.

Naser, M.R., Abdolkarim K., Ebrahim A. and Moral M. (2011). Effect of plant spacing and number of seedling per hill of yield and yield components of rice (Rezado variety). World Applied Sci. J., 12(10) 1754-1759.

Nayak, B.C., Dalai, B.B. and Chodhury, B.K. (2003). Response of hybrid rice to date of planting, spacing and Seedling rate during wet season. Indian J. Agron., 48(3): 172-174.

Obulamma, U. and Reddeppa, R. (2002). Effect of spacing and number on growth and yield of hybrid rice. J. Res. ANGRAU., 30(1): 76-78.

Pandey, R.C., Pandey, R.P., Vyas, O.P. and Pandey, A.K. (1987). Effect of number of seedlings per hill on grain yield of rice. Indian J. Agril. Sci., 71(5): 337338.

Pariyani, A.K., and Naik, K.R. (2004). Effect of nitrogen levels and seedling number on yield attributes and yield of rice hybrids. J. Soils Crops., 14(2): 234-236.

Prasad, R., Sharma, S.N., Singh, S. and Zaman, F.U. (1998). Productivity of Hybrid rice 'Pusa HR3' under late planting conditions. Ann. Agril. Res., 19 (1): 92-93.

Raghuvanshi, S.K.S., Paradker, U.K., Gupta, R.K. and Jain, S.C. (1986). Effect of spacing, number of seedlings per hill and $\mathrm{N}$ doses on performance of rice grown in sodic clay soil. Curr. Agril., 10(1-2): 53-55.

Rajarathinam, P. and Balasubramaniyan, P. (1999). Optimum plant population, seedling densities and $\mathrm{N}$ levels for medium duration hybrid rice. Indian $J$. Agril. Sci., 69(8): 583-585.

Rajendran, K. and Ganesa, R.V. (2014). Effect of age of seedlings on growth and yield of rice.IndianJ. Adv Plant Res, Vol. 1(5): 62-66.

Rajesh, V. and Thanunathan, K. (2003).Effect of seedling age, number and spacing on yield and nutrient uptake of traditional Kambanchamba rice. Madras Agric. J., 90(1-3): 47-49.

Rao, K.S. and Moorthy, B.T.S. (2003). Hybrid rice technology for achieved higher yield during dry season in coastal Orissa. Indian Farm., 53(3): 4-5.

Rao, S., Chalapathi, M.V., Thimmegowda, S., Devakumar, N. and Rao, G.G.E. (1999). Response of hybrid rice to seedling densities and fertilizer levels. Mysore J. Agril. Sci., 33(2): 193-196.

Reddy, M.D. and Mitra, B.N. (1984). Effect of seedling age and population density on yield and yield components of rice in intermediate deep water situation.Thai. J. Agril. Sci., 17(2): 89-95.

Roshan, N.M., Keshavarz, A., Azarpour, E. and Moradi, M. (2011). Effect of plant spacing and number of seedlings per hill of yield and yield components rice (rezajo variety). World Appl. Sci. J., 12(10): 1754-1759.

Safdar, M.A., Ali, A., Muhammad, S., Sarwar, G. and Awan, T.H. (2008). Effect of transplanting dates on paddy yield of fine grain rice genotypes. Pak. J. Bot., 40(6):2403 - 4211.

Sahoo, N.C. and Rout, L. (2004). Effect of seedling age and plant density on growth, yield and nutrient uptake in 
high yielding rice varieties and hybrids. Indian J. Argon., 49(1): 72-75.

Sawa, M., Tsukihana, K., Sakmoto, J. and Yutsuhaoshi, Y. (1988). Cultivation experiments on number of rice seedlings per hill. Report of the Tohuke Branch Crop Science Society, Japan, 31: 25-28.

Shah, M.H., Khushu, M.K., Khandey, B.A. and Bali, A.S. (1991). Effect of spacing and seedling per hill on transplanted rice under late sown conditions. Indian J. Agron., 36(2): 274-275.

Shah, M.H., Khusu, M.K. and Bali, A.S. (1987). Effect of spacing and number of seedlings per hill on transplanted rice. Oryza., 24(1): 67-69.

Shrirame, M.D., Rajgire, H.J. and Rajgire, A.H. (2000). Effect of spacing and seedling number per hill on yield attributes and yield of rice hybrids under lowland condition. J. SoilCrop., 10(1): 109-113.

Siddhu, A.S.; Agrawal, G.C. and Singh, N.J. (1988). Effect of irrigations and seedling age and number on rice yield. IRRN., 13(5): 24.

Soga, Y. and Nazaki, M. (1975). Studies on the relation between seasonal changes of carbohydrate accumulates and the stage of generative growth in rice plant. Proc. Crop Sci. Soc. Japan., 28: 105108.

Srinivasulu, K. (1997). Performance of rice hybrid under different methods and densities of planting. Oryza., 34(1): 7374.

Srinivasulu, K., Veeraraghavaih, R. and Madhavi, K. (1999b). Yield and nutrient uptake of rice hybrid as influenced by planting method and seedling rate. Oryza., 36(3).

Srivastav, G.K. and Tripathi, R.S. (1998). Response of hybrid and composite rice to number of seedling and planting geometry. Ann. Agric. Res., 19(2): 235236.

Thawait, D., Patel, A.K., Kar, S., Sharma, M.K. and Meshram, M.R. (2014). Performance of transplanted scented rice (Oryza sativa L.) under SRI based cultivation practices sustainable method for crop production. The Bio. scan., 9(2): 539-542.

Varma, A.K., Pandey, N. and Tripathi, S. (2002). Effect of transplanting spacing and number of seedlings on productive tillers, Spikelet sterility, grain yield and harvest index of hybrid rice. IRRN., 27(1): 51.

Zhang, P.J., Zhan, X.C., Zhang, M., Jiangg, F.J. and Li, A. (2004). Effect of transplanting densities and seedling number per hill on yield of medium Japonica hybrid rice 'III You 98'. Hybrid Rice, 19(1): 43-44.

Zhang, X.G. and Hung, Y.K. (1990). Effect of seedlings per hill on individual rice plant yield and yield components. IRRN, 15(4): 21-22.

\section{How to cite this article:}

Gurjar G. N., Sanjay Swami and Meena N. K. 2018. Effect of Age of Seedling and Number of Seedlings per Hill on Growth and Yield of Low land Rice Cultivation in Asia - A Review. Int.J.Curr.Microbiol.App.Sci. 7(06): 3751-3760. doi: https://doi.org/10.20546/ijcmas.2018.706.439 